Research Article

\title{
Evaluation of Phytoremediation Potential of Vetiver Grass (Chrysopogon zizanioides (L.) Roberty) for Wastewater Treatment
}

\author{
Mahdi Mahmoudpour (D), Siamak Gholami ${ }^{1},{ }^{1}$ Majid Ehteshami ${ }^{1},{ }^{1}$ and Marjan Salari (iD) \\ ${ }^{1}$ Civil Engineering Department, $K$ N Toosi University of Technology, Tehran, Iran \\ ${ }^{2}$ Civil Engineering Department, Sirjan University of Technology, Kerman, Iran \\ Correspondence should be addressed to Marjan Salari; salari.marjan@gmail.com
}

Received 7 July 2021; Revised 24 August 2021; Accepted 26 August 2021; Published 16 September 2021

Academic Editor: Veronica Calado

Copyright (C) 2021 Mahdi Mahmoudpour et al. This is an open access article distributed under the Creative Commons Attribution License, which permits unrestricted use, distribution, and reproduction in any medium, provided the original work is properly cited.

\begin{abstract}
Water pollution is one of the most critical global issues. Meanwhile, the problem of water pollution of rivers especially in Iran is rising due to expansion of agricultural and industrial applications. Due to a large number of sewer catchments, there are some dam reservoirs like ZHAVE in Iranian state of Kurdistan that have not been able to collect significant amount of water since last 10 years. Removal of heavy metals as contaminants from runoffs and recycling of water is a necessity and a vital issue in the world. Various methods and standards are invented and used to isolate and remove all types of pollutants. This study focuses on the purification and removal of contaminants in water sources using the phytoremediation method by introducing Vetiver grass species in the case of floating treatment wetland (FTW). This study's preliminary purpose is to investigate a practical remedial solution and improvement methodology for the water quality of reservoirs and rivers by growing the floating Vetiver island method. The results show that following parameters such as COD by $97 \%$, TN by $90 \%$, phosphorus by $66 \%$, TDS by $26 \%$, and evapotranspiration by $40 \%$ were reduced. Therefore, we concluded that for a wastewater with varying neutrient concentrations such as in ZHAVE dam, concentration of nutrients $\mathrm{N}$ and $\mathrm{P}$ was controlled and consequently inhibition and prevention of the eutrophication of water resources in the medium and long term became possible due to reduction in the rate of evaporation from reservoirs.
\end{abstract}

\section{Introduction}

Floating treatment wetland (FTW) is a suitable wastewater treatment system for developing countries in the tropics, which requires access to land and high temperatures for biodegradation [1]. These wetlands can treat municipal, domestic, industrial wastewater, aquaculture wastewater, and so on [2-4]. In particular, many practical studies and various purification methods have been conducted to investigate the possibility of reusing wastewater to irrigate agricultural lands [5-9]. Plant-based water treatment methods are effective, cost-effective, and sustainable [10]. One of the crucial factors in applying the phytoremediation method is choosing the right plant [11].
The use of aquatic plants in phytoremediation is beneficial because they have an extraordinary capacity to absorb and destroy pollutants [12]. For example, removal efficiency of $\mathrm{NO}_{3}^{-}-\mathrm{N}, \mathrm{NH}_{4}{ }^{+}-\mathrm{N}$, and $\mathrm{P}$ in Typha Angustifolia are 51.6\%, $56.5 \%$, and $9.1 \%$, respectively [13]. In particular, Vetiver has been studied and used by various researchers to treat different types of wastewater [13-18]. The Vetiver system (VS), as a new phytoremediation method based on Vetiver grass, was recognized for the first time in 1995 due to its "super absorbent" properties suitable for leachate and effluent produced disposal from landfills and wastewater treatment plants in Australia [19].

Vetiver is a hydrophilic plant with physiological properties such as absorbing soluble nutrients such as $\mathrm{N}$ and $\mathrm{P}$, 
reducing $\mathrm{BOD}, \mathrm{COD}$, TSS, heavy metals, and high resistance to pesticides [20]. In the research study done by Kabata, the concentration of lead in Vetiver is considered toxic to the plant if roots and leaves exceed $30 \mathrm{ppm}$ [21].

According to Ash and Truong, the results show that Vetiver has the highest percentage of nitrogen and phosphorus removal than other plants. Vetiver can remove $13,688 \mathrm{~kg} / \mathrm{ha}$ of nitrogen per year in hydroponic environments, which is even 6 times better than potted conditions and 12 times better than conditions planted in dry soil. It is also 6 times more efficient than the other two media in terms of nitrogen removal in hydroponic environments [22]. Plant growth depends on physical properties such as temperature, soil texture, soil moisture, and chemical properties such as $\mathrm{pH}$, salinity, and heavy metals concentration. Still, this plant can grow in harsh environmental conditions and tolerate these conditions [23, 24].

Although Vetiver has a high tolerance range, it is susceptible to lack of light and does not tolerate shade. However, if the shade is removed from the plant, it returns to its normal state and begins to grow and take root. However, the plant dries out and dies if the lack of light continues [25]. Vetiver grows relatively fast. Its crown is 1 to 2 meters high, and its root has a depth of 3 to 4 meters, which is branched and intertwined and can penetrate different layers of soil and weave them together [26]. Wang tested three species of Vetiver plants with different genotypes at different temperatures. In the presented results, the Vetiver shows the best growth rate at a temperature between 25 and 35 degrees Celsius. Research has shown that the plant has the fastest root growth rate of $4 \mathrm{~cm}$ per day at $25^{\circ} \mathrm{C}$ soil. In other words, in 75 days, the Vetiver's root can reach a length of 3 meters in the best situation [27]. The leaves and stems of Vetiver can be dried to a dark brown color. Its compost can be used. This compost is very nutritious and beneficial for the soil. Leaves are also used for livestock, but it is better to use them in combination because the crude protein in these leaves is less than other plants [24].

Alsghayer et al. investigated PAHs' removal efficiency from wastewater using a constructed wetland where Vetiver was planted. Removal efficiencies of phenanthrene and benzo and pyrene have been reported to be $67 \%, 66 \%$, and $73 \%$, respectively [28].

Koupai et al. investigated the efficiency of phytoremediation using Vetiver in the Isfahan landfill's leachate quality. According to the results obtained in this study, the removal efficiencies of $\mathrm{COD}, \mathrm{BOD}_{5}$, phosphate, and nitrate using Vetiver after 21 days were $68,60,82$, and $83 \%$, respectively [29]. Ky et al. evaluated the efficiency of nutrient removal by floating treatment wetland using Vetiver some studies, by using the floating treatment islands system in containers. Darajeh et al. investigated the treatment of palm oil plant effluent (POME), a pollutant produced by the palm oil industry, using vetiver system (VST) technology. This technology was first used to treat POME to reduce biochemical oxygen demand (BOD) and chemical oxygen demand (COD). The results showed that vetiver was able to reduce BOD up to 90 at low POME concentration and 60 at high POME concentration, while control sets (plant-free) were only able to reduce 15 BODs. The reduction in COD was $94 \%$ at low POME concentrations and 39\% at high concentrations, while the control showed only $12 \%$ reduction $[30,31]$.

RoyChowdhury et al. (2021) used the vetiver plant to treat wastewater containing insensitive ammunition such as 3-nitro1,2,4-triazol-5-one (NTO). Various NTO treatment technologies are being developed for wastewater treatment of industrial ammunition facilities. This is the first study to discover the potential plant treatment of industrial NTO wastewater using Vetiver grass (Chrysopogon zizanioides L.). The results showed that vetiver can effectively remove NTO from wastewater and also transfer NTO from the root to the stem $[32,33]$.

Panja et al. reviewed the removal efficiency of antibiotics and nutrients from the secondary effluent. Removal efficiencies of antibiotics, nitrate, phosphate, TOC, and COD from secondary effluents using Vetiver have been reported to be more than $90,40,60,50$, and $40 \%$, respectively [34]. Maharjan and Pradhanang investigated the ability of Vetiver to treat wastewater. The results showed that, after one month, the removal efficiencies of $\mathrm{BOD}_{5}$, chloride, nitrate, phosphate, hardness, and alkalinity were reported to be $71.03 \%, 42.9 \%, 93.93 \%, 88.4 \%, 46.4 \%$, and $22.2 \%$, respectively. Based on these results, Vetiver seems to be very effective in wastewater treatment with high phosphate and nitrate amounts [35]. Mathew et al. investigated the efficiency of Vetiver in wastewater treatment of an organizational kitchen. In this study, the removal efficiencies of $\mathrm{BOD}_{5}, \mathrm{COD}$, and total coliform were reported to be $85 \%$, $90 \%$, and $85 \%$, respectively [36]. The present study focuses on the purification and removal of contaminants in water sources using the phytoremediation method by introducing Vetiver grass species in the case of floating treatment wetland (FTW). This study's preliminary purpose is to investigate a practical remedial solution and improvement methodology for the water quality of reservoirs and rivers by growing the floating Vetiver island method.

\section{Materials and Methods}

For preparation of synthetic wastewater, chemicals used were purchased. Pepton (Sigma Aldrich CAS number 9107940-2), $\mathrm{FeSO}_{4}$ (Sigma Aldrich CAS number 7720-78-7 ), $\mathrm{KH}_{2} \mathrm{PO}_{4}$ (Sigma Aldrich CAS number 7778-77-0), $\mathrm{NaCl}$ (Sigma Aldrich CAS number 7647-14-5), CaCl (Sigma Aldrich CAS number 7720-78-7 ), $\mathrm{MgSO}_{4} \cdot 7 \mathrm{H}_{2} \mathrm{O}$ (Sigma Aldrich CAS number 10034-99-8), $\mathrm{Ca}\left(\mathrm{NO}_{3}\right)_{2}$ (Sigma Aldrich CAS number 13477-34-4), and $\left(\mathrm{NH}_{4} \mathrm{NO}_{3} \mathrm{CAS}\right.$ number 6484-52-2) were purchased from Sigma Aldrich. In this study, plant samples were obtained from a greenhouse with a $37.2682^{\circ} \mathrm{N}, 49.5891^{\circ} \mathrm{E}$ coordinate position located in Rasht city, Iran.

2.1. Pilot Preparation. The pilot was made using three polyethylene containers of 126 liters. The container perimeter was covered with black plastic to reduce the penetration of sunlight as much as possible and to prevent the production of moss and algae that cause errors in the test 
results. The first container contains 12 floating plants with the addition of dilute and nonaerated sewage. The second container has 12 floating plants with dilute and aerated wastewater equipped with an aeration pipe. The tube is placed in a spiral with a distance of $5 \mathrm{~cm}$ from the container's bottom. Holes in the pipe's surface were drilled at intervals of 5 to $8 \mathrm{~cm}$ to completely disrupt the wastewater and perform adsorption and treatment operations at a higher speed. The third container has 12 floating plants with concentrated wastewater $=(5$ times dilute wastewater $)$ and without aeration. The floating surface was made of compressed ionolite with $5 \mathrm{~cm}$ thickness and a 25 density to have more strength and continue to float on the water's surface, taking into account the plant's weight. The ionolithic plate containing Vetiver seedlings with the same root and stem length was placed floating on the aqueous medium so that more than $99 \%$ of the water surface was covered.

2.2. Preparation of Artificial Sewage. Three 126 liter containers containing 100 liters of synthetic wastewater were selected in the laboratory to evaluate the purification power of Vetiver in ambient air conditions. According to Table 1, synthetic materials were chosen separately, and 100 liters were added to each container. Preliminary data after adding artificial wastewater are shown in Table 1 and Figure 1.

According to Figure 1, all three pots have the same physical and visual conditions (similar number of plants, container, ionolite, cover, and so on) and also the height of taller plants using cutting operations is considered equal to $30 \mathrm{~cm}$, which all plants should be $30 \mathrm{~cm}$ high.

The amount of the adsorbed (mg) per unit mass of Vetiver $(\mathrm{g}) q_{e}$ was obtained by mass balance using the following equation [37]:

$$
q_{e}=\frac{C_{i}-C_{e}}{m} V,
$$

where $C_{i}$ and $C_{e}$ are the initial and equilibrium concentrations of the nitrogen and phosphate $(\mathrm{mg} / \mathrm{L}), m$ is the mass of Vetiver (g), and $V$ is the volume of the solution (L).

\section{Results and Discussion}

Seven tests have been performed on each container during one month, in which a total of 21 wastewater samples were tested. Table 2 shows the preliminary results of qualitative experiments obtained from the cultivation of Vetiver. The changes of $T, \mathrm{pH}, \mathrm{EC}, \mathrm{TN}, \mathrm{TP}$, and COD parameters in 30 days are presented in Table 2.

3.1. Evaporation and Transpiration. The percentage of water consumption (total evaporation and transpiration) in the samples of Vetiver culture medium in Figure 2 is considerable. Accordingly, the aerated container has the most evaporation due to the rising air pressure. While in the sample of wastewater with higher concentration, it has the least evaporation. Calculations show that during a week in one square meter of free water surface in September, approximately 48 liters of evaporation have been done.
3.2. $C O D$ Results. Floating islands were very effective in reducing COD. At the end of the one month, COD decreased about $33 \%$ in a container containing concentrated wastewater, even though the plant had almost given up and lost its efficiency. This reduction is very significant in the other two containers, which include more dilute wastewater.

It turns out that in a container containing dilute nonaerated wastewater, after about three weeks, we observed $0.90 \%$ removal rate according to the numbers and graphs related to COD removal (Figure 3). However, in a container containing dilute wastewater with aeration, the system quickly began to reduce $\mathrm{COD}$ so that after ten days, the rate of COD reduction reached more than $0.90 \%$. Furthermore, in both cases, one month after the start of the test, the removal percentages of $0.93 \%$ and $0.97 \%$ were obtained for nonaerated and aerated containers, respectively. Therefore, these results demonstrate very desirable effect of the system and justify using of this method to reduce COD in polluted waters (Figure 3).

\subsubsection{Results of Statistical Analysis with RSM for the First} Response (COD). According to Table 3, parameters A, C, and $\mathrm{D}$ are effective in the study response.

The correlation coefficient $\left(R^{2}\right)$ was 0.99 , which indicates that the fitting model follows the data very well. The equation of the first-order polynomial model resulting from the analysis of the test results is as follows:

$$
\mathrm{COD}=161.97-83.5 \mathrm{~A}+159.66 \mathrm{~B}+456.36 \mathrm{C}+201.43 \mathrm{D} \text {. }
$$

In the above equation, the parameters $\mathrm{A}, \mathrm{B}, \mathrm{C}$, and $\mathrm{D}$ are temperature, $\mathrm{pH}, \mathrm{EC}$, and time, respectively. Figure 4 shows the interaction of independent parameters affecting the COD response from data analysis. According to the figure, the COD value decreases with increasing temperature at $\mathrm{pH}$ 7.5. The lowest $\mathrm{COD}$ value was obtained at $26.2^{\circ} \mathrm{C}$ and $\mathrm{EC}=500 \mathrm{~cm} / \mu$ s over 31 days.

3.3. TN Results. Many researchers have found that nitrogen removal efficiency in treatment using plants is always higher than without plants in studying plants' role $[38,39]$. In the $\mathrm{TN}$ removal test, except for the container containing concentrated wastewater, we saw a $65 \%$ increase in nitrogen sources. As shown in Figure 4, in the following two samples, we see a favorable reduction of total nitrogen from the wastewater source.

In a container containing dilute nonaerated wastewater, $50 \%$ of the total nitrogen was removed from the beginning of the experiment until the tenth day. However, after that, the reduction operation was slower, and finally the removal percentage reached 55 at the end of the experiments, which is nonsignificant compared with the first days of the investigation. In the aerated container, the nitrogen removal operation had a better process so that on the seventh day, more than $50 \%$ of the total nitrogen was removed by the system. In the second week, the removal percentage reached $80 \%$, but after that the graph's slope gradually decreased, and the rate of nitrogen removal decreased (Figure 4). 
TABle 1: Concentration of synthetic materials (based on OECD) in samples of Vetiver medium.

\begin{tabular}{|c|c|c|c|c|}
\hline Row & Type of composition & $\begin{array}{c}\text { Container a } \\
\text { Dilute sewage } \mathrm{x}(\mathrm{g} / 100 \mathrm{~L})\end{array}$ & $\begin{array}{c}\text { Container b } \\
\text { Dilute sewage } \mathrm{x}(\mathrm{g} / 100 \mathrm{~L})\end{array}$ & $\begin{array}{l}\text { Container c } \\
\text { Concentrated sewage x5 }(\mathrm{g} / 100 \mathrm{~L})\end{array}$ \\
\hline 1 & Pepton & 25.6 & 25.6 & 128 \\
\hline 2 & $\mathrm{FeSO}_{4}$ & 1 & 1 & 5 \\
\hline 3 & $\mathrm{Ca}\left(\mathrm{NO}_{3}\right)_{2}$ & 16.4 & 16.4 & 82 \\
\hline 4 & $\mathrm{NH}_{4} \mathrm{NO}_{3}$ & 0.16 & 0.16 & 0.8 \\
\hline 5 & $\mathrm{KH}_{2} \mathrm{PO}_{4}$ & 0.28 & 0.28 & 1.4 \\
\hline 6 & $\mathrm{NaCl}$ & 0.07 & 0.07 & 0.35 \\
\hline 7 & $\mathrm{CaCl}$ & 0.4 & 0.4 & 0.2 \\
\hline 8 & $\mathrm{MgSO}_{4} .7 \mathrm{H}_{2} \mathrm{O}$ & 0.02 & 0.02 & 0.1 \\
\hline
\end{tabular}

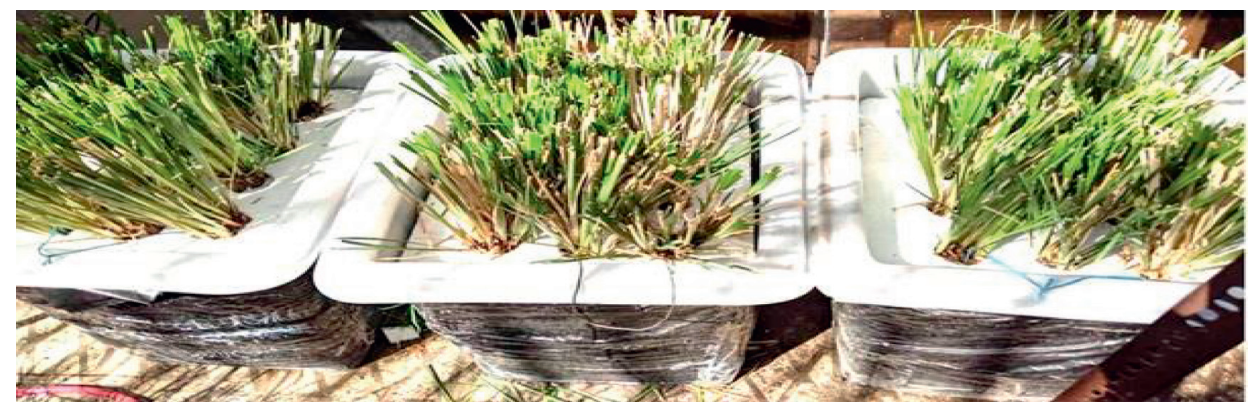

(a)

(b)

(c)

Figure 1: Comparison of floating Vetiver in water of Khajeh Nasiruddin University laboratory: (a) dilute sewage with aeration; (b) dilute sewage without aeration; (c) concentrated sewage without aeration.

TABLE 2: Results as soon as synthetic wastewater is added to each of the test containers.

\begin{tabular}{|c|c|c|c|c|c|c|c|c|c|}
\hline The average of the measured parameter & Day & $T\left({ }^{\circ} \mathrm{C}\right)$ & $\mathrm{pH}$ & $\begin{array}{c}\mathrm{EC} \\
(\mu \mathrm{s} / \mathrm{cm})\end{array}$ & $\begin{array}{c}\mathrm{TDS} \\
(\mathrm{mg} / \mathrm{l})\end{array}$ & $\begin{array}{c}\mathrm{DO} \\
(\mathrm{mg} / \mathrm{l})\end{array}$ & $\begin{array}{c}\mathrm{TN} \\
(\mathrm{mg} / \mathrm{l})\end{array}$ & $\begin{array}{c}\mathrm{TP} \\
(\mathrm{mg} / \mathrm{l})\end{array}$ & $\begin{array}{l}\mathrm{COD} \\
(\mathrm{mg} / \mathrm{l})\end{array}$ \\
\hline \multirow{7}{*}{ Container a dilute sewage $\mathrm{x}$, aerated } & $\begin{array}{c}0 \text { (before } \\
\text { phytoremediation) }\end{array}$ & 24.2 & 7.02 & 554 & 350 & 1.7 & 34.32 & 0.47 & 344 \\
\hline & 7 & 24.9 & 7.9 & 488 & 300 & 4.5 & 16.21 & 0.3 & 99 \\
\hline & 10 & 26.5 & 8.01 & 488 & 300 & 4.7 & 13.49 & 0.25 & 28 \\
\hline & 4 & 25.3 & 7.86 & 478 & 290 & 5.1 & 7.11 & 0.23 & 20 \\
\hline & 19 & 25.4 & 7.9 & 467 & 280 & 5.9 & 5.2 & 0.19 & 16 \\
\hline & 24 & 25.9 & 8.1 & 458 & 270 & 5.4 & 4.1 & 0.17 & 12 \\
\hline & 31 & 26.2 & 8.15 & 446 & 260 & 5.9 & 3.5 & 0.16 & 11 \\
\hline \multirow{7}{*}{ Container $\mathrm{b}$ diluted wastewater $\mathrm{x}$ nonaerated } & $\begin{array}{c}0 \text { (before } \\
\text { phytoremediation) }\end{array}$ & 24.2 & 7.02 & 554 & 350 & 1.7 & 34.32 & 0.47 & 344 \\
\hline & 7 & 24.8 & 6.86 & 489 & 310 & 1.3 & 22.84 & 0.45 & 166 \\
\hline & 10 & 26.6 & 7.03 & 484 & 300 & 0.9 & 18.5 & 0.4 & 84 \\
\hline & 14 & 25 & 7.17 & 464 & 290 & 1.2 & 16.25 & 0.38 & 46 \\
\hline & 19 & 25.2 & 7.1 & 427.4 & 270 & 1.1 & 16 & 0.34 & 35 \\
\hline & 24 & 25.8 & 7.2 & 395.7 & 250 & 1.2 & 15.5 & 0.32 & 27 \\
\hline & 31 & 26 & 7.1 & 379.9 & 240 & 1.2 & 15.3 & 0.27 & 24 \\
\hline \multirow{7}{*}{$\begin{array}{l}\text { Container } \mathrm{c} \text { concentrated wastewater } 5 \mathrm{x} \\
\text { nonaerated }\end{array}$} & $\begin{array}{c}0 \text { (before } \\
\text { phytoremediation) }\end{array}$ & 24.3 & 6.89 & 1270 & 840 & 0.5 & 117.8 & 1.92 & 760 \\
\hline & 7 & 24.8 & 7.03 & 1529 & 1020 & 0.4 & 138.41 & 2.83 & 622 \\
\hline & 10 & 25.9 & 7.15 & 1623 & 1030 & 0.4 & 171.46 & 3.15 & 642 \\
\hline & 14 & 23.4 & 7.2 & 1540 & 1050 & 0.5 & 183.4 & 3.41 & 572 \\
\hline & 19 & 23.7 & 7.1 & 1588.96 & 1060 & 0.45 & 188 & 3.7 & 550 \\
\hline & 24 & 23.9 & 6.9 & 1633.93 & 1090 & 0.35 & 192 & 3.9 & 520 \\
\hline & 31 & 24 & 6.9 & 1678.90 & 1120 & 0.38 & 195 & 3.95 & 510 \\
\hline
\end{tabular}




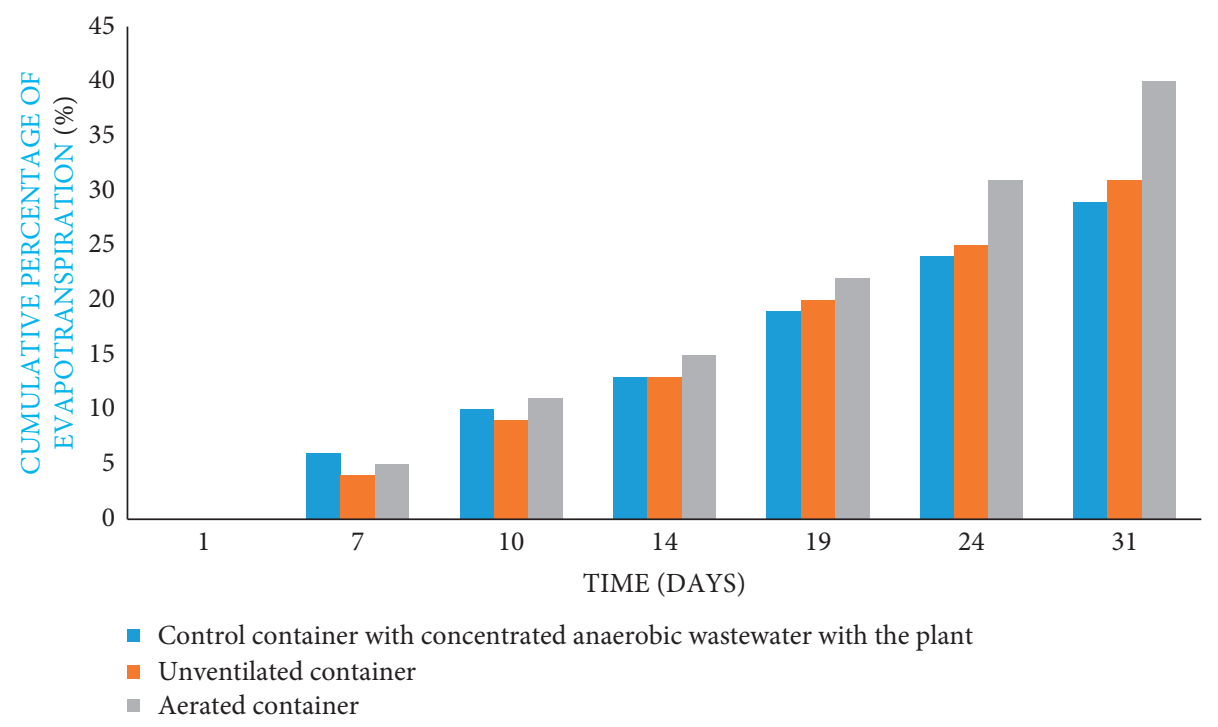

FIGURE 2: Results of cumulative percentage of evapotranspiration in the water container with Vetiver sampling by days.

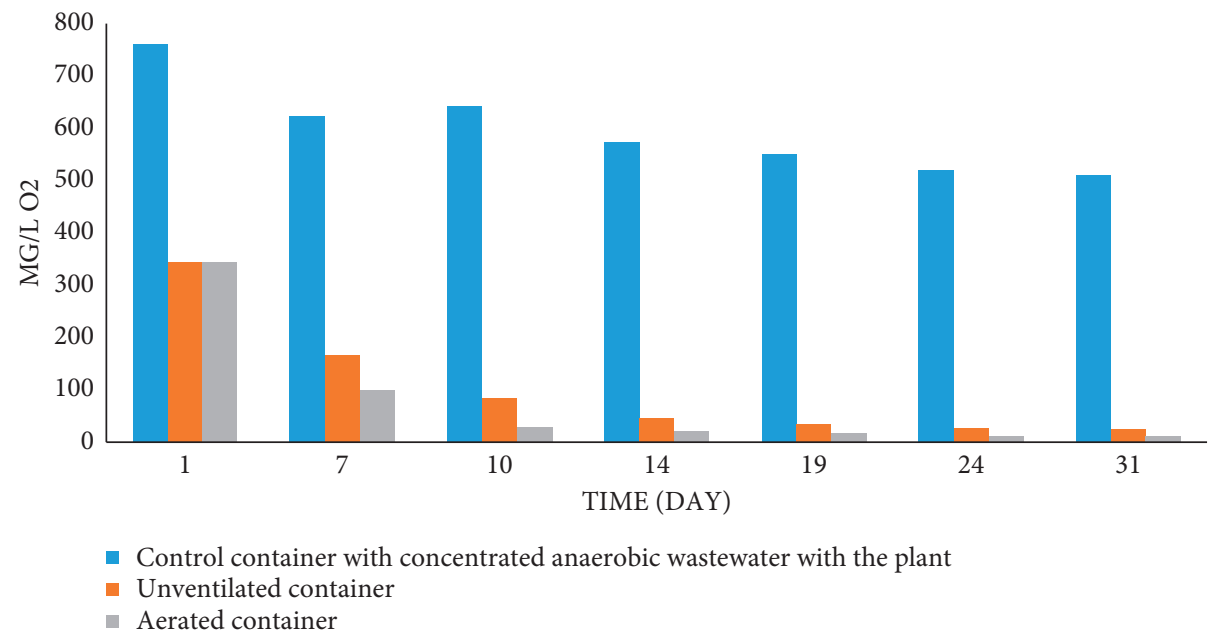

FIgURE 3: Results of mean COD in water container with Vetiver sampling by days.

TABLE 3: ANOVA analysis of variance for the first answer.

\begin{tabular}{|c|c|c|c|c|c|c|}
\hline Source & Sum of squares & Degrees of freedom & Average of squares & $F$ value & $P$ value & Significant \\
\hline Model & 88257.30 & 4 & 22064.32 & 157.48 & 0.0062 & Significant \\
\hline A: temperature & 2201.97 & 1 & 2201.97 & 15.92 & 0.05 & Significant \\
\hline $\mathrm{B}: \mathrm{pH}$ & 893.87 & 1 & 893.87 & 6.46 & 0.1261 & Significant \\
\hline C: EC & 4715.25 & 1 & 4715.25 & 34.08 & 0.0281 & Significant \\
\hline D: time & 4954.47 & 1 & 4954.47 & 35.81 & 0.0268 & Significant \\
\hline
\end{tabular}

As shown in Figure 4, this removal process continued until the last day, and at the end of the month, we achieved a $90 \%$ removal rate. However, the removal percentage is not expected to increase significantly with the continuation of the experiment.

3.3.1. Result of Statistical Analysis with RSM for the Second Response (TN). Parameters C and D are effective in the study response, according to Table 4.
The correlation coefficient $R^{2}$ was 0.98 , which indicates that the fitting model follows the data very well. The firstorder polynomial model equation resulting from the experimental results' analysis is given in the following relation:

$$
\mathrm{TN}=17.37-6.26 \mathrm{~A}+22.76 \mathrm{~B}+45.76 \mathrm{C}+12.22 \mathrm{D} .
$$

In the above equation, the parameters $\mathrm{A}, \mathrm{B}, \mathrm{C}$, and $\mathrm{D}$ are temperature, $\mathrm{pH}, \mathrm{EC}$, and time, respectively. Figure 5 shows the interaction of independent parameters affecting the TN 


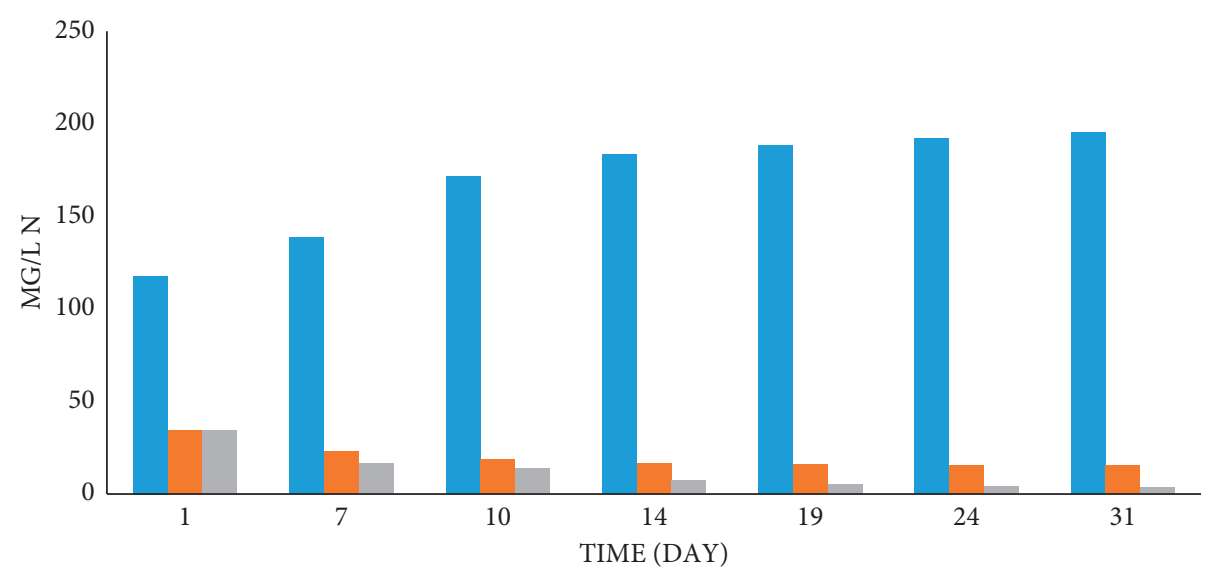

- Control container with concentrated anaerobic wastewater with the plant
- Unventilated container
- Aerated container

Figure 4: Results of the average total TN nitrogen in the water container with Vetiver sampling by days.

TABLE 4: ANOVA analysis of variance for the second answer.

\begin{tabular}{lcccccc}
\hline Source & Sum of squares & Degrees of freedom & Average of squares & $F$ value & $P$ value & Significant \\
\hline Model & 711.35 & 4 & 177.84 & 36.11 & 0.0271 & Significant \\
A: temperature & 12.38 & 1 & 12.38 & 2.51 & 0.2537 & Nonsignificant \\
B: pH & 18.34 & 1 & 18.34 & 3.73 & 0.1934 & Nonsignificant \\
C: EC & 47.40 & 1 & 47.40 & 9.62 & 0.0901 & Significant \\
D: time & 18.25 & 1 & 18.25 & 3.71 & 0.0941 & Significant \\
\hline
\end{tabular}

response resulting from data analysis. $\mathrm{TN}$ value decreases with increasing temperature at $\mathrm{pH} 7$, according to the figure. The lowest $\mathrm{TN}$ was obtained at $26.5^{\circ} \mathrm{C}$ and $\mathrm{EC}=500 \mathrm{~cm} / \mu \mathrm{s}$ during 31 days.

3.4. TP Results. According to the study of Wang et al., the decomposition of phosphorus by microorganisms in treatment using plants is more than without plants [40]. It should be noted that in addition to adsorption, phosphorus can also be removed by chemical precipitation [41]. In phosphorus-related experiments, we eventually encountered a decrease in total phosphorus in both containers over one month. In a container containing dilute, aerated wastewater, aerobic bacteria begin to absorb and remove phosphorus, and the trend is a decreasing graph as shown in the figure. Phosphorus value decreases by up to $50 \%$ within 10 days, and by the end of one month, this reduction reaches $66 \%$. Phosphorus values increase by $80 \%$ after a week in an anaerobic container and then decrease so that at the end of one month, the total phosphorus rate drops to $42 \%$. The reason for the initial increase is that the polyphosphates are not detected in the experiments, and anaerobic-friendly polyphosphate bacteria begin to break down these polyphosphates because the anaerobic state occurs in this sample and mineral phosphorus is released as a result of their activity. In this time, mineral phosphorus is determined in experiments. This problem is the reason for this increase in phosphorus in Figure 5. In the next step, phosphorophilic bacteria absorb and consume the produced phosphates, and they chart a downward trend from this point. The floating system with Vetiver works well as it is known, and the total phosphorus is reduced in wastewater with this concentration.

3.4.1. Results of Statistical Analysis with RSM for the Third Response (TP). Parameters A, B, C, and D are effective in the investigated response, according to Table 5. The correlation coefficient of $R^{2}$ was 0.99 , which indicates that the model fits well.

The first-order polynomial model equation resulting from the experimental results' analysis is given in the following equation:

$$
\mathrm{TP}=0.2991-0.0757 \mathrm{~A}+0.1956 \mathrm{~B}+0.3809 \mathrm{C}+0.0901 .
$$

In the above equation, the parameters $\mathrm{A}, \mathrm{B}, \mathrm{C}$, and $\mathrm{D}$ are temperature, $\mathrm{pH}, \mathrm{EC}$, and time. Figures 6-9 show the interaction of independent parameters affecting COD, DO, $\mathrm{TN}$, and $\mathrm{TP}$ responses resulting from data analysis. According to the figures, the TP value decreases with increasing temperature at $\mathrm{pH}$ 7. The lowest $\mathrm{TP}$ value was obtained at $36.5^{\circ} \mathrm{C}$ and $\mathrm{EC}=500 \mathrm{~cm} / \mu$ s over 31 days.

3.5. Plant Root Growth Results. The presence of plants increases the biofilms formed around the roots, which play an essential role in oxidation, absorption, and so on. In floating treatment wetland with higher biomass growth rates, better nitrogen transfer has been observed [41]. A set of 


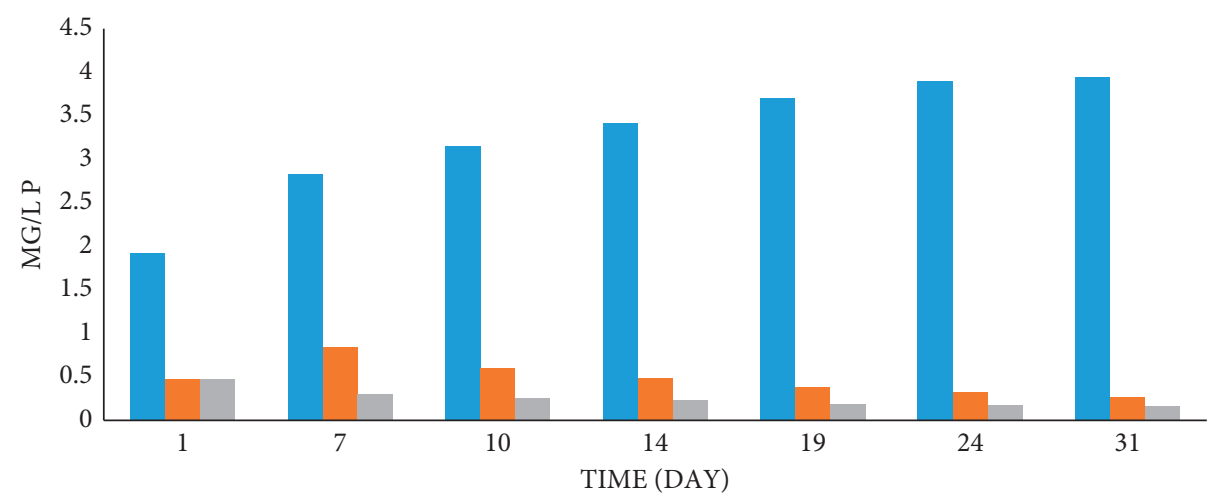

Control container with concentrated anaerobic wastewater with the plant
Unventilated container
Aerated container

FIGURE 5: Results of the average total TP phosphorus in the water container with Vetiver sampling by days.

TABLE 5: ANOVA analysis of variance for the third answer.

\begin{tabular}{|c|c|c|c|c|c|c|}
\hline Source & Sum of squares & Degrees of freedom & Average of squares & $F$ value & $P$ value & Significant \\
\hline Model & 0.0684 & 4 & 0.0171 & 2515.80 & 0.0004 & Significant \\
\hline A: temperature & 0.0018 & 1 & 0.0018 & 255.56 & 0.0039 & Significant \\
\hline $\mathrm{B}: \mathrm{pH}$ & 0.0013 & 1 & 0.0013 & 189.61 & 0.0052 & Significant \\
\hline C: EC & 0.0033 & 1 & 0.0033 & 464.45 & 0.0021 & Significant \\
\hline D: time & 0.0010 & 1 & 0.0010 & 140.04 & 0.0071 & Significant \\
\hline
\end{tabular}

microorganisms interactions are involved in treating wastewater in artificial ponds, which attach to plant roots and decompose contaminants to survive [42, 43].

In this study, the root growth diagram shows that the container with lower contaminants concentrations has grown more without aeration. The root material has taken a diverse and thicker shape. This difference may be due to the plant trying to gain more nutrients. In an aerated container, the roots easily reach these sources and grow naturally because the movement of food is done by the pressure of air bubbles. They are mixed continuously, and they do not precipitate. However, in the case of aeration, the roots have to go deep to reach food sources.

As shown in Figures 10-12, the roots are still growing normally after 2 weeks because the nutrients are watersoluble, and there is no competition. However, the roots quickly start to grow vertically and do not branch after absorbing these substances. This problem is beneficial for using in water reservoirs of dams with a low or medium concentration of nutrients because nutrients are absorbed by root growth. The rate of root growth, as it is known, during 30 days of research for the Vetiver plant in an unaerated container with diluted wastewater and aerated container with diluted wastewater is on average equal to 25 and $20 \mathrm{~cm}$, respectively.

However, various researchers have conducted several studies on the effectiveness of Vetiver, for example, Kirti et al. compared the phytoremediation efficiency of vetiver and lemongrass in pots against compared simulation of $\mathrm{Ni}$ Cd battery electrolyte waste (EW). They observed that the accumulation of nickel ( $\mu \mathrm{gg}-1)$ in shoots (36.8) and roots
(252.9) of Vetiver was higher than that of lemongrass 12.5 and 7.79, respectively. Therefore, Vetiver was more resistant to EW toxicity than lemongrass because it had fewer morphological parameters and lower rise in TBARS against the doses of EW. Also Vetiver roots had higher Niel accumulation than $\mathrm{Cd}$ in $\mathrm{EW}$-contaminated soil in comparison with lemongrass [44].

In another study, Siyar et al. evaluated the use of Vetiver grass in plating real contaminated soils around a smelter. The studied parameters including voltage gradient (1-2 V/ $\mathrm{cm}$ ), different electric field (AC-DC), saturated and unsaturated state, and Eh-pH changes for plating Vetiver performance were investigated. Vetiver grows for 21 days. Then, three different voltage gradients $(1,2 \mathrm{DC} \mathrm{V} / \mathrm{cm}$ and $2 \mathrm{AC} \mathrm{V/}$ $\mathrm{cm}$ ) were applied to the soil for 8 hours a day for 21 days and were compared with control cells without electric field (PR). The results showed that the use of DC current significantly changes the values of Eh-pH, and this is in contrast to the use of AC current, which causes minor changes. Absorption of total metals in the stems of plants treated with AC with BCF $>1$ was much higher than PR and DC. Due to the speed of movement and plant health, if AC current is applied for a long time, it can have better results in electrical treatment of Vetiver plant through the plant extraction process [45]. Ng et al. evaluated the growth performance, accumulation process, and adsorption skills of Vetiveria zizanioides (Linn.) Nash. In both single and mixed heavy metals (Cd, Pb, $\mathrm{Cu}$, and $\mathrm{Zn}$ )-disodium EDTA-enhanced contaminated soil. Results showed that all accumulation of heavy metals were significantly higher $(p<0.05)$ in both lower and upper roots and tillers of Vetiver grass for $\mathrm{Cd}+\mathrm{Pb}+\mathrm{Cu}+\mathrm{Zn}+$ EDTA 


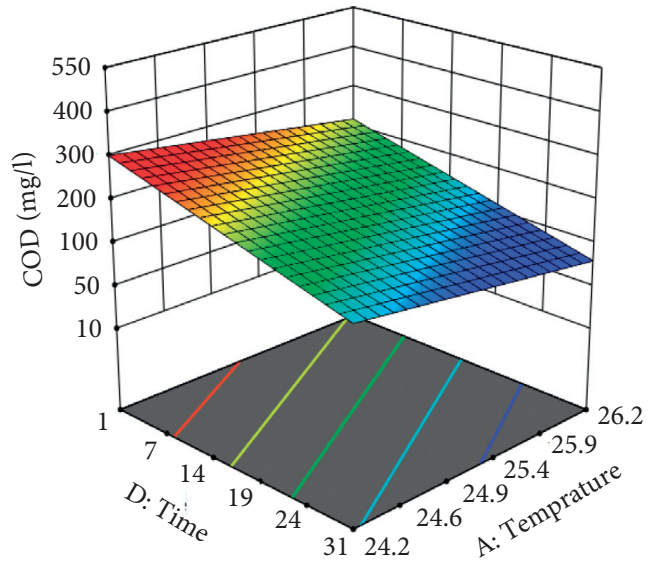

FIGURE 6: The effect of independent parameter interaction on COD response.

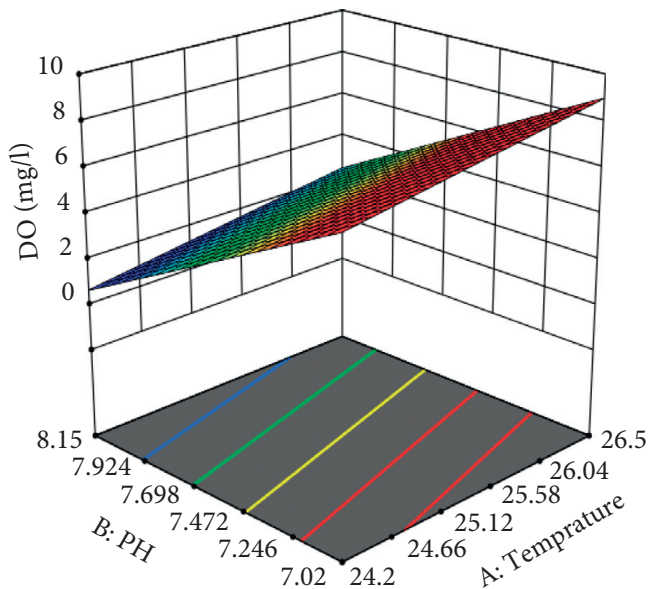

FIgURE 7: The effect of independent parameter interaction on DO response.

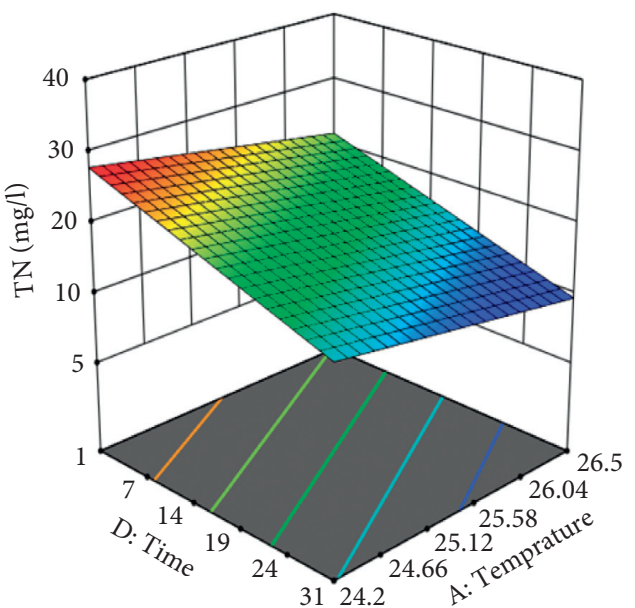

FIgURE 8: The effect of independent parameter interaction on TN response.

treatments as compared with the control. Only Zn + EDTA treatment collected the highest amount of zinc (8068 \pm $407 \mathrm{mg} / \mathrm{kg}$ ) while the highest accumulation of copper was $(1977 \pm 293 \mathrm{mg} / \mathrm{kg})$ and lead was $(1096 \pm 759 \mathrm{mg} / \mathrm{kg})$ in the composition. In general, the accumulation trend of heavy metals in Vetiver was $\mathrm{Zn}>>>\mathrm{Cu}>\mathrm{Pb}>>\mathrm{Cd}$ for all treatments, respectively [46]. Nugroho et al. evaluated the uptake and removal of heavy metals by Vetiver (Chrysopogon zizanoides L.) in metal-contaminated waters. Vetiver was planted in synthetic plating wastewater containing different 


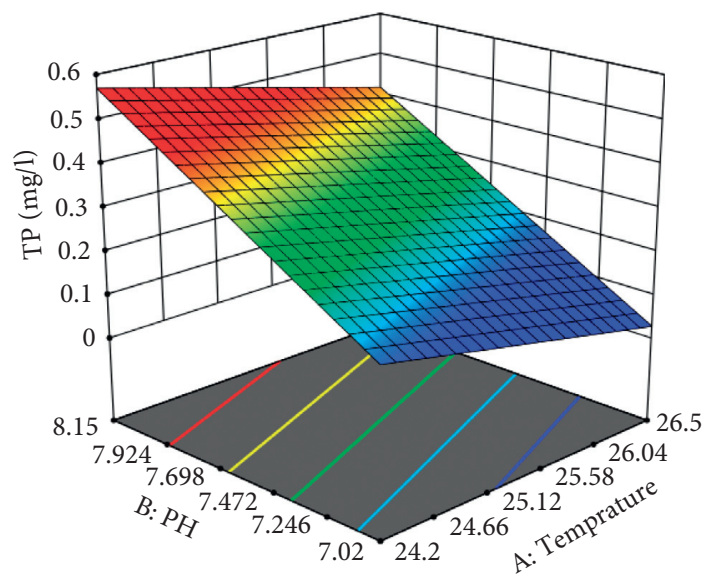

Figure 9: The effect of independent parameter interaction on TP response.

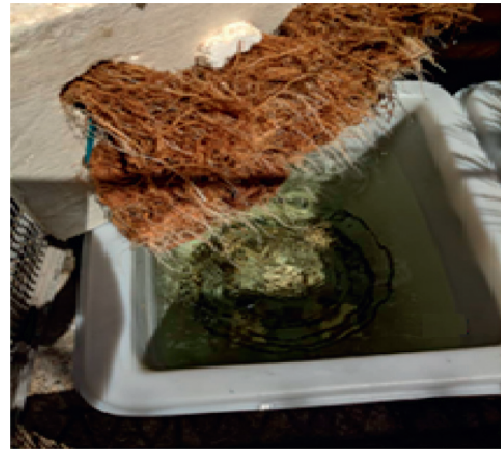

(a)

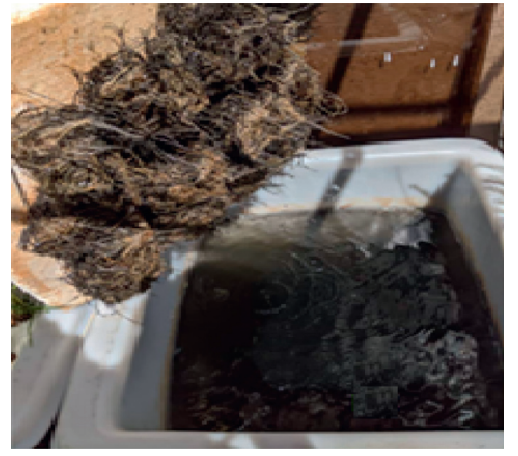

(b)

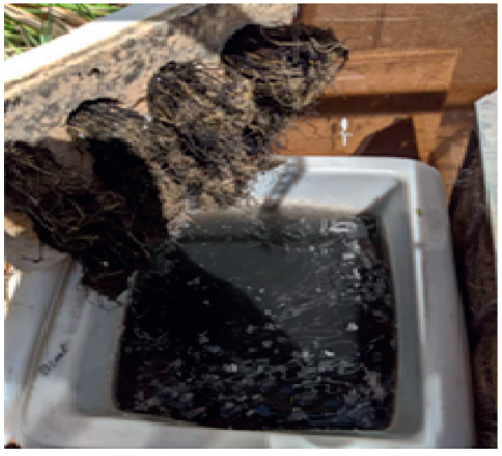

(c)

Figure 10: Comparison of the condition of floating Vetiver roots in the water of Khajeh Nasir al-Din laboratory after 15 days: (a) dilute sewage with aeration to the root of the Vetiver; (b) dilute sewage without aeration; (c) concentrated wastewater without aeration to the Vetiver.

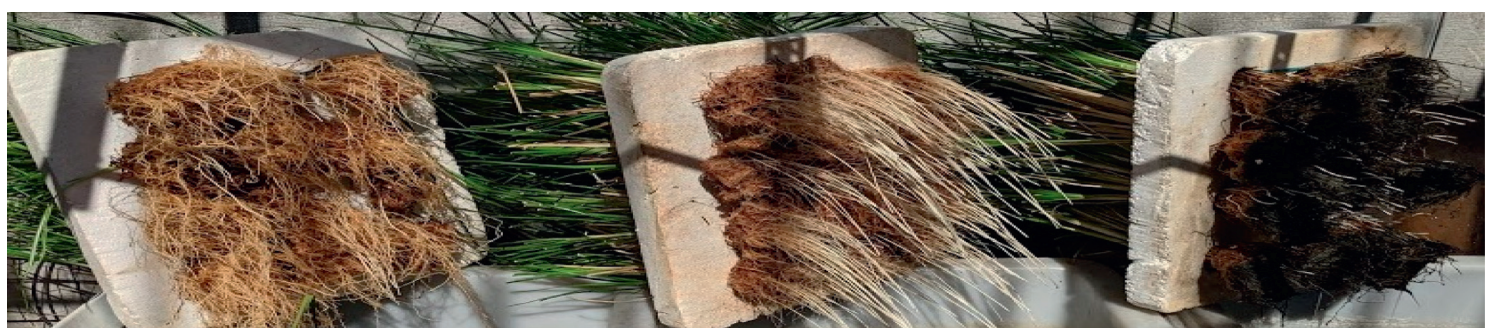

(a)

(c)

Figure 11: Comparison of the condition of floating Vetiver roots in the water of Khajeh Nasir al-Din laboratory after 30 days: (a) dilute sewage with aeration to the root of the vetiver; (b) dilute sewage without aeration; (c) concentrated wastewater without aeration to the Vetiver.

levels (low, medium, and high) of chromium (Cr) and nickel (Ni). Water, roots, and twigs were collected periodically to determine $\mathrm{Cr}$ and $\mathrm{Ni}$ levels using atomic absorption spectroscopy (AAS). The maximum absorption of $\mathrm{Cr}$ and $\mathrm{Ni}$ was $127.21 \mathrm{mg} / \mathrm{kg} /$ day and $60.15 \mathrm{mg} / \mathrm{kg} /$ day, respectively, while the removal of chromium and nickel was $1.09 \mathrm{mg} / \mathrm{kg} /$ day and $12.24 \mathrm{mg}$, respectively. The results show that Vetiver plant has a good efficiency for removing heavy metals from aquatic environments [47]. In another study, Datta et al. investigated the potential of using Vetiver as a plant purifier to remove tetracycline (TC) from aqueous media. Vetiver plants were grown for 60 days in a greenhouse in a TC-contaminated hydroponic system. Preliminary results indicate that complete elimination of tetracycline occurred within 40 days in all TC treatments. The initial concentration of TC had a significant effect $(p<0.0001)$ on the removal kinetics of tetracycline in roots and stem tissues, which confirmed root uptake and transfer to the stem. In general, 


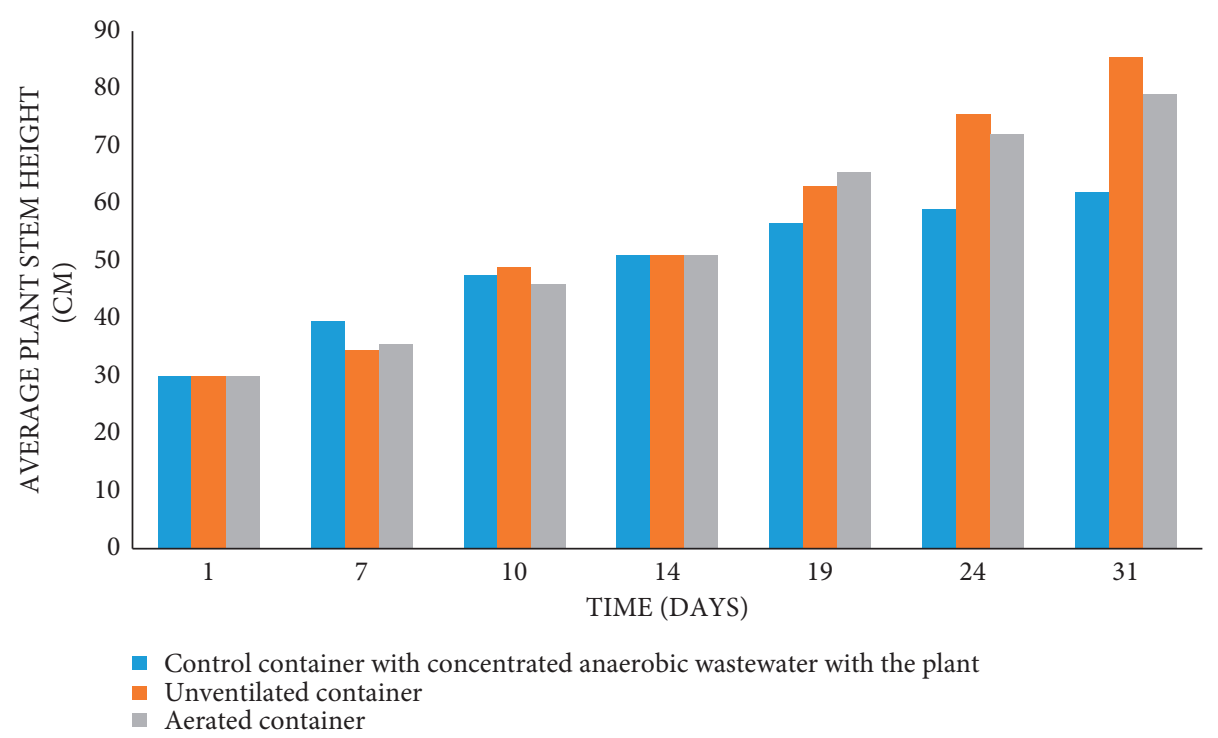

FIgURE 12: Results of mean plant stem height Vetiver in water except for sampling days.

past and present studies prove the effectiveness of plant phytoremediation, especially Vetiver in water and wastewater treatment of various pollutants [48]. These man-made made structures of floating islands could be further improved in their filtration efficiencies and survival when a chitosan-based filter was added which could reduce the overall heavy metal ion concentration of polluted water [49].

\section{Conclusion}

According to studies, the use of wastewater treatment by floating islands in developed countries receives more attention. As mentioned, this method is considered more than others, with many benefits, especially its economics. It is better to pay more attention to such practices in undeveloped countries, following the developing and developed countries. Therefore, research has been done to increase its efficiency and apply them to optimize artificial floating islands. We will now briefly review the highlights of this research.

The highest percentage of COD removal was related to the container containing dilute aerated wastewater (97\%); the lowest reduction rate was related to the container containing dilute unaerated sewage (93\%). The highest TN removal percentage was related to the container containing dilute aerated waste (90\%). The lowest rate of reduction was related to the container containing dilute unaerated wastewater (55\%). In total phosphorus, the highest percentage of removal was related to the container containing dilute aerated wastewater $(66 \%)$. The lowest rate of reduction (42\%) was related to the container containing dilute unaerated wastewater.

The highest evaporation percentage is related to the container containing dilute aerated wastewater (40\%); the lowest evaporation percentage is associated with the container containing dilute unaerated sewage (31\%). In general, the efficiency of this project is high and worth the investment. Since the leaves and roots of this plant have economic value, it compensates its initial capital investment and starts to create profit after a short time. Due to the above results, the aerated system had a higher efficiency in other experiments, except for the evaporation section. However, it is recommended to use an unaerated system on a large scale since both the energy cost of the aerators and evaporation are removed and reduced, respectively.

\section{Data Availability}

The data used to support the findings of this study are included within the article.

\section{Conflicts of Interest}

The authors declare that they have no conflicts of interest.

\section{Acknowledgments}

The authors thank Iran National Science Foundation (INSF) (grant no. 96006027) for their supports.

\section{References}

[1] S. Kantawanichkul, S. Sattayapanich, and F. Van Dien, "Treatment of domestic wastewater by vertical flow constructed wetland planted with umbrella sedge and Vetiver grass," Water Science and Technology, vol. 68, no. 6, pp. 1345-1351, 2013.

[2] S. Dallas, B. Scheffe, and G. Ho, "Reedbeds for greywater treatment-Case study in Santa Elena-Monteverde, Costa Rica, Central America," Ecological Engineering, vol. 23, no. 1, pp. 55-61, 2004.

[3] J. Vymazal, "The use constructed wetlands with horizontal sub-surface flow for various types of wastewater," Ecological Engineering, vol. 35, no. 1, pp. 1-17, 2009.

[4] K. Skrzypiecbcef and M. H. Gajewskaad, "The use of constructed wetlands for the treatment of industrial wastewater," Journal of Water and Land Development, vol. 34, no. 1, pp. 233-240, 2017. 
[5] M. Farid, M. Irshad, M. Fawad et al., "Effect of cyclic phytoremediation with different wetland plants on municipal wastewater," International Journal of Phytoremediation, vol. 16, no. 6, pp. 572-581, 2014.

[6] Z. Ali, A. Mohammad, Y. Riaz, U. M. Quraishi, and R. N. Malik, "Treatment efficiency of a hybrid constructed wetland system for municipal wastewater and its suitability for crop irrigation," International Journal of Phytoremediation, vol. 20, no. 11, pp. 1152-1161, 2018.

[7] G. R. Rakhshandehroo, M. Salari, and M. R. Nikoo, "Optimization of degradation of ciprofloxacin antibiotic and assessment of degradation products using full factorial experimental design by Fenton homogenous process," Global Nest Journal, vol. 20, no. 2, pp. 324-332, 2018.

[8] M. Salari, G. R. Rakhshandehroo, and M. R. Nikoo, "Multiobjective optimization of ciprofloxacin antibiotic removal from an aqueous phase with grey taguchi method," Journal of Water and Health, vol. 16, no. 4, pp. 530-541, 2018.

[9] M. Salari, G. R. Rakhshandehroo, and M. R. Nikoo, "Degradation of Ciprofloxacin antibiotic by homogeneous Fenton oxidation: hybrid AHP-PROMETHEE method, optimization, biodegradability improvement and identification of oxidized by-products," Chemosphere, vol. 206, pp. 157-167, 2018.

[10] S. Panja, D. Sarkar, and R. Datta, "Removal of tetracycline and ciprofloxacin from wastewater by Vetiver grass (Chrysopogon zizanioides (L.) Roberty) as a function of nutrient concentrations," Environmental Science and Pollution Research, vol. 27, no. 28, pp. 34951-34965, 2020.

[11] R. Seroja, H. Effendi, and S. Hariyadi, "Tofu wastewater treatment using Vetiver grass (Vetiveria zizanioides) and zeliac," Applied Water Science, vol. 8, no. 1, pp. 1-6, 2018.

[12] H. M. G. Mustafa Hayder, "Recent studies on applications of aquatic weed plants in phytoremediation of wastewater: a review article," Ain Shams Engineering Journal, vol. 12, no. 1, pp. 355-365, 2020.

[13] K. B. S. N. Jinadasa, N. Tanaka, S. Sasikala, D. R. I. B. Werellagama, M. I. M. Mowjood, and W. J. Ng, "Impact of harvesting on constructed wetlands performance-a comparison between Scirpus grossus and Typha angustifolia," Journal of Environmental Science and Health, Part A, vol. 43, no. 6, pp. 664-671, 2008.

[14] N. Roongtanakiat and C. Prapai, "Uptake potential of some heavy metals by Vetiver grass," Agriculture and Natural Resources, vol. 35, pp. 46-50, 2001.

[15] X. Lu, M. Kruatrachue, P. Pokethitiyook, and K. Homyok, "Removal of cadmium and zinc by water hyacinth, Eichhornia crassipes," ScienceAsia, vol. 30, no. 2, p. 93, 2004.

[16] N. Dudai, E. Putievsky, D. Chaimovitch, and M. Ben-Hur, "Growth management of vetiver (Vetiveria zizanioides) under mediterranean conditions," Journal of Environmental Management, vol. 81, no. 1, pp. 63-71, 2006.

[17] M. M. Mirzaee, M. ZakeriNia, and M. Farasati, "The effects of phytoremediation of treated urban wastewater on the discharge of surface and subsurface drippers (case study: Gorgan wastewater treatment plant in northern Iran)," Cleaner Engineering and Technology, vol. 4, no. 1, pp. 100-210, 2021.

[18] R. Datta, P. Das, S. Smith et al., "Phytoremediation potential of vetiver grass [chrysopogon zizanioides (L.)] for tetracycline," International Journal of Phytoremediation, vol. 15, no. 4, pp. 343-351, 2013.

[19] P. B. H. M. E. C. H. Truong, "Vetiver system for wastewater treatment," Pacific Rim Vetiver Network Technical Bulletin, vol. 201, p. 2, 2001.
[20] H. Effendi, B. Widyatmoko, B. A. Utomo, and N. T. M. Pratiwi, "Ammonia and orthophosphate removal of tilapia cultivation wastewater with Vetiveria zizanioides," Journal of King Saud University Science, vol. 32, no. 1, pp. 207-212, 2020.

[21] A. Kabata-Pendias and H. Pendias, "Biogeochemistry of trace elements," Trace Elements from Soil to Human, vol. 2nd, no. 2, 2001.

[22] R. Ash and P. Truong, The Use of Vetiver Grass for Sewerage Treatment, Sewage Management QEPA Conference, Cairns, Australia, 2004.

[23] S. Panja, D. Sarkar, and R. Datta, "Vetiver grass (Chrysopogon zizanioides) is capable of removing insensitive high explosives from munition industry wastewater," Chemosphere, vol. 209, pp. 920-927, 2018.

[24] N. Chomchalow and K. Chapman, "Other uses and utilization of vetiver,” Tech. Bull. No. 2002/1, PRVN/ORDPB, pp. 486-491, Bangkok, Thailand.

[25] X. Hanping, A. Huixiu, and H. Daoquan, "Effect of environmental factors on vetiver grass growth," Chinese Journal of Ecology, vol. 5, no. 2, 1994.

[26] P. A. Dalton, R. J. Smith, and P. N. V. Truong, "Vetiver grass hedges for erosion control on a cropped flood plain: hedge hydraulics," Agricultural Water Management, vol. 31, no. 1-2, pp. 91-104, 1996.

[27] Y. W. Wang, "The root extension rate of Vetiver under different temperature treatments," Journal of Chemical Information and Modeling, vol. 53, no. 9, pp. 1689-1699, 2019.

[28] R. Alsghayer, A. Salmiaton, T. Mohammad, A. Idris, and C. F. Ishak, "Removal efficiencies of constructed wetland planted with phragmites and vetiver in treating synthetic wastewater contaminated with high concentration of PAHs," Sustainability, vol. 12, no. 8, p. 3357, 2020.

[29] J. A. Koupai, M. A. Jamalian, and M. M. Dorafshan, "Improving isfahan landfill leachate quality by phytoremediation using vetiver and phragmites plants in green space irrigation," Water and Wastewater, vol. 31, no. 3, pp. 101-111, 2020.

[30] N. M. Ky, N. T. Q. Hung, N. C. Manh, B. Q. Lap, H. T. T. Dang, and A. Ozaki, "Assessment of nutrients removal by constructed wetlands using reed grass (phragmites australis L.) and vetiver grass (Vetiveria zizanioides L.)," Journal of the Faculty of Agriculture, Kyushu University, vol. 65, no. 1, pp. 149-156, 2020.

[31] N. Darajeh, A. Idris, P. Truong, A. A. Aziz, R. Abu Bakar, and H. Che Man, "Phytoremediation potential of vetiver system technology for improving the quality of palm oil mill effluent," Advances in Materials Science and Engineering, vol. 2014, Article ID 683579, 10 pages, 2014.

[32] N. Pavlineri, N. T. Skoulikidis, and V. A. Tsihrintzis, "Constructed Floating Wetlands: a review of research, design, operation and management aspects, and data meta-analysis," Chemical Engineering Journal, vol. 308, pp. 1120-1132, 2017.

[33] Roy Chowdhury, A. P. Mukherjee, S. Panja, R. Datta, C. Christodoulatos, and D. Sarkar, "Evidence for phytoremediation and phytoexcretion of NTO from industrial wastewater by vetiver grass," Molecules, vol. 26, no. 1, p. 74, 2021.

[34] S. Panja, D. Sarkar, and R. Datta, "Removal of antibiotics and nutrients by Vetiver grass (Chrysopogon zizanioides) from secondary wastewater effluent," International Journal of Phytoremediation, vol. 22, no. 7, pp. 764-773, 2020.

[35] A. Maharjan and S. Pradhanang, "Potential of vetiver grass for wastewater treatment," Environment and Ecology Research, vol. 5, no. 7, pp. 489-494, 2017. 
[36] M. Mathew, S. C. Rosary, M. Sebastian, and S. M. Cherian, "Effectiveness of vetiver system for the treatment of wastewater from an institutional kitchen," Procedia Technology, vol. 24, pp. 203-209.

[37] A. Gupta, M. Yunus, and N. Sankararamakrishnan, "Zerovalent iron encapsulated chitosan nanospheres - a novel adsorbent for the removal of total inorganic arsenic from aqueous systems," Chemosphere, vol. 86, no. 2, pp. 150-155, 2012.

[38] B.-H. Lee and M. Scholz, "What is the role of Phragmites australis in experimental constructed wetland filters treating urban runoff?" Ecological Engineering, vol. 29, no. 1, pp. 87-95, 2007.

[39] T. H. Dan, L. N. Quang, N. H. Chiem, and H. Brix, "Treatment of high-strength wastewater in tropical constructed wetlands planted with Sesbania sesban: horizontal subsurface flow versus vertical downflow," Ecological Engineering, vol. 37, no. 5, pp. 711-720, 2011.

[40] R. Wang, V. Baldy, C. Périssol, and N. Korboulewsky, "Influence of plants on microbial activity in a vertical-downflow wetland system treating waste activated sludge with high organic matter concentrations," Journal of Environmental Management, vol. 95, pp. S158-S164, 2012.

[41] L. Du, Q. Chen, P. Liu et al., "Phosphorus removal performance and biological dephosphorization process in treating reclaimed water by Integrated Vertical-flow Constructed Wetlands (IVCWs)," Bioresource Technology, vol. 243, pp. 204-211, 2017.

[42] H. D. Tran, H. M. T. Vi, H. T. T. Dang, and R. M. Narbaitz, "Pollutant removal by Canna Generalis in tropical constructed wetlands for domestic wastewater treatment," Global Journal of Environmental Science and Management, vol. 5, no. 3, pp. 331-344, 2019.

[43] J. Vymazal, "Constructed wetlands for wastewater treatment," Water, vol. 2, no. 3, pp. 530-549, 2010.

[44] Kriti, N. Basant, J. Singh et al., "Nickel and cadmium phytoextraction efficiencies of Vetiver and lemongrass grown on $\mathrm{Ni}$-Cd battery waste contaminated soil: a comparative study of linear and nonlinear models," Journal of Environmental Management, vol. 295, Article ID 113144, 2021.

[45] R. Siyar, F. Doulati Ardejani, M. Farahbakhsh, P. Norouzi, M. Yavarzadeh, and S. Maghsoudy, "Potential of Vetiver grass for the phytoremediation of a real multi-contaminated soil, assisted by electrokinetic," Chemosphere, vol. 246, Article ID 125802, 2020.

[46] C. Ng, A. Boyce, M. Abas, N. Mahmood, and F. Han, "Phytoassessment of Vetiver grass enhanced with EDTA soil amendment grown in single and mixed heavy metal-contaminted soil," Environmental Monitoring and Assessment, vol. 191, no. 7, p. 434, 2019.

[47] A. P. Nugroho, E. S. B. Butar, E. A. Priantoro, L. Sriwuryandari, Z. B. Pratiwi, and T. Sembiring, "Phytoremediation of electroplating wastewater by Vetiver grass (Chrysopogon zizanoides L.)," Scientific Reports, vol. 11, no. 1, Article ID 14482, 2021.

[48] R. Datta, P. Das, S. Smith et al., "Phytoremediation potential of Vetiver grass [Chrysopogon zizanioides (L.)] for tetracycline," International Journal of Phytoremediation, vol. 15, no. 4, pp. 343-351, 2013.

[49] S. Gholami, M. Dimde, D. Braatz, J. Müller, R. Haag, and O. Wagner, "Reusable biopolymer based heavy metal filter as plant protection for phytoremediation," Environmental Technology \& Innovation, vol. 19, Article ID 101005, 2020. 